Author version: Environ. Monit. Assess.: 155(1-4); 2009; 245-256

\title{
Abundance of sewage-pollution indicator and human pathogenic bacteria in a tropical estuarine complex
}

\author{
G. S. Nagvenkar and N. Ramaiah* \\ National Institute of Oceanography \\ Dona Paula, Goa 403004
}

\begin{abstract}
Studies on abundance and types of various pollution indicator bacterial populations from tropical estuaries are rare. This study was aimed to estimate current levels of pollution indicator as well as many groups of human pathogenic bacteria and their seasonal variations in different locations in Mandovi and Zuari Rivers in the central west coast of India. The sampling covered the estuarine and upstream regions of these rivers representing premonsoon (May 2005), monsoon (September 2006) and post-monsoon (November 2005). Both the abundance and types of autochthonous and allochthonous microbial populations in the near shore environments are affected by land drainages, domestic sewage outfalls and other discharges. The overall ranges (and their mean abundance; no. $\mathrm{ml}^{-1}$ ) of the monitored groups of bacteria were: total coliforms: 029047 (3134ml ${ }^{-1}$ ); total streptococci: 3-14597 (798); total vibrios: 13-42275 (2530); Escherichia coli: 0-1333 (123); Vibrio cholerae: 0-3012 (207); Salmonella spp: 0-1646 (90); Streptococcus faecalis: 0-613 (88) and Aeromonas spp: 0-2760 (205). In general, abundance of sewage pollution indicator bacteria such as total coliforms and total streptococci was lower than that reported from many other locations worldwide.
\end{abstract}

*corresponding author; tel: +91 832 2450515; fax: +91 8322450602

email: ramaiah@nio.org

Key words: Sewage pollution indicators, Human pathogenic bacteria, tropical estuaries, marine environmental contamination, allochthonous bacteria 


\section{Introduction:}

Environmental surveys are necessary for understanding and documenting the occurrence and distribution of pollution indicator and human pathogenic bacteria. In order to quantify and understand their relationship with relevant environmental factors, several investigators have examined distribution of these groups of bacteria and certain viruses in coastal waters (Colwell et al. 1977; Marchand 1986; Patti et al. 1987; Piccolomini et al. 1987; Ramaiah and Chandramohan 1993; Ruiz et al. 2000; Ramaiah and De 2003). Mortality and survival rates of fecal contamination indicator Escherichia coli in the marine regimes have also been studied (Thom et al. 1992; Darakas 2001). Findings from these studies affirm persistence of allochthonous microflora in the marine environment. Further, different species of bacteria including pathogenic ones (Colwell et al. 1981; Xu et al. 1982; Huq et al. 1984; McCarthy and Khambaty 1994; McCarthy et al. 1996; Wait and Sobsey 2000; Darakas 2001; Ramaiah et al. 2002a) survive in seawater for one to several weeks. Once introduced into the marine environment, allochthonous pathogens of human health concerns can disperse far and wide to other regions.

Land drainages, domestic sewage outfalls, and other discharges alter the abundance and type of both autochthonous and allochthonous microbial populations in the near shore environments (Colwell et al. 1977; Marchand 1986; Patti et al. 1987; Piccolomini et al. 1987). Further, higher proportions of allochthonous microflora that not only survive but also out-compete native microflora are certain to cause undesirable ecosystem imbalances (Colwell et al. 1981; Huq et al. 1984). An understanding of incidence and distribution of bacterial species, their physiological characteristics including pathogenicity to both plants and animals is important for gaining insights on the presence of harmful microbial communities. In order to assess the importance of microbial pathogens in the marine environment, information on the microbial load in any given ecosystem is mandatory. Once at hand, such data can be used for evolving advisories on controlling or regulating their abundance in any ecological situation. These aspects have been widely investigated and, the important coastal pollution surveillance needs no overemphasis (Fujioka et al. 1997). However, studies on abundance and types of various pollution indicator bacterial populations from tropical estuaries are rare. 
This study was carried out to document current levels of pollution indicator bacteria as well as some groups of human pathogenic bacteria in different areas in both the estuaries and offshore waters of Goa on the central west coast of India. The study also focused on understanding the seasonal differences in all microbial groups looked for, so as to provide an annual cycle of microbial load.

\section{Materials and Methods:}

Various sampling locations sampled are shown in Figure 1. Zuari and Mandovi are the two major rivers of Goa. With the rainfall in excess of 2500mm annually (Shankar et al. 2004), these rivers drain enormous quantities of land materials during June-September, the months of intense rains. Apart from this, there are routine releases of urban sewage effluents in the range of 10 million litres per day (Sawkar et al. 2003). Further, 300 barges move iron-ore daily into the harbor from mining sites upstream of both the rivers for loading $~ 15-20$ ore carriers for export. Thus, the region receives barge-related wastes in addition to the effluents as above. Being an international tourist destination, Goa receives over 1.2 million visitors annually. Including the lower stretches of Mandovi and Zuari, its coastal spaces are of recreational interest.

Sampling was carried out during May 2005 representing pre-monsoon period (March-May), November 2005 (post- monsoon: November- February) and September 2006 (monsoon: JuneOctober). Samples were collected from many locations offshore, in the Marmugao Bay and from upstream stretches of both the rivers. Since the sampling was combined for other biological measurements, samples for microbiological analysis were collected from 22 different sampling sites. Sites 1- 3 were located offshore (station depths 16 to $20 \mathrm{~m}$ ). Sites 4-7, 9-12 and, 18-22 were in Marmugao Bay. Sites 14-16 were in Mandovi and 8, 13 and 24 in Zuari mouth and upstream zone. This sampling was so planned to represent coastal and estuarine zones of Mandovi and Zuari. These locations were chosen to generally represent a seaward gradient in land drainages and other effluents. To avoid contamination from surface micro-layer, water samples were collected from $c a .1 \mathrm{~m}$ below the surface by using Niskin ( $5 \mathrm{~L}$ capacity, General Oceanics, FL) samplers. One hundred milliliters of sample from each location was collected in to pre-sterilized bottles. Approximately $100 \mathrm{~g}$ of sediment samples collected by a van Veen grab at 
different locations were removed aseptically into polythene bags. Up to $10 \mathrm{ml}$ samples of zooplankton collected using a Heron Tranter net (200 $\mu \mathrm{m}$ mesh sized bolting silk) were taken out for microbiological analyses. All samples were collected with precautions required for microbiological analysis, held on ice in an icebox and transported to the laboratory for further analysis.

During all the three collections, water and sediment samples were collected from all locations listed above for quantification of different groups of bacteria. Also examined were the zooplankton samples collected from stations 4, 9, 16, 18 and 24. Following groups of bacteria were quantified. Specific media (Hi-Media) used for enumerating are listed against them.

$\begin{array}{lll}\text { Nutrient Agar } & - & \text { Total viable counts (TVC) } \\ \text { McConkey Agar } & - & \text { Total coliforms (TC) } \\ & & \text { Escherichia coli (EC) } \\ \text { Thiosulphate citrate bile salts sucrose (TCBS) Agar - } & \text { Total vibrios (VLO) } \\ & \text { Vibrio cholerae (VC) } \\ & - & \text { Vibrio parahaemolyticus (VP) } \\ \text { Hi- Crome Salmonella Agar } & - & \text { Total Streptococci (TS) } \\ \text { M Enterococcus Agar } & & \text { Streptococcus faecalis (SF) } \\ \text { Enterococcus confirmatory Agar } & - & \text { Total streptococci (TS) } \\ \text { Aeromonas Isolation Agar } & & \text { Streptococcus faecalis (SF) }\end{array}$

Most of the media were prepared with the addition of aged seawater to attain a minimum of 15 PSU salinity and, autoclaved. Only TCBS was prepared using deionised water and steam sterilized as required. All plates were prepared 5 days prior to sampling. Aliquots of $0.1 \mathrm{ml}$ and $0.2 \mathrm{ml}$ of water samples were spread plated in triplicate on nutrient agar plates prepared at least 5 days prior to plating. And aliquots of $0.2 \mathrm{ml}, 0.3 \mathrm{ml}$ and $0.4 \mathrm{ml}$ of water samples were spread plated in triplicate on all the selective Media mentioned above. These volumes spread on to the medium in $90 \mathrm{~mm}$ dia plates were easily absorbed without any trace of liquid. The Seawater 
nutrient agar (SWNA) plates were incubated at room temperature $\left(26 \pm 0.5{ }^{\circ} \mathrm{C}\right)$ and all other plates of specific media were incubated at $37^{\circ} \mathrm{C}$ at least for 24 to $48 \mathrm{~h}$ and final counts of colonies were noted. When very high counts of any specific group of bacteria were observed in any media ca. $24 \mathrm{~h}$ incubation, water samples held in a refrigerator were diluted 10 or 100 fold and reexamined as above by spread plating method. In addition to these plate counts, total direct counts (TDC) of bacteria were enumerated from all the water samples collected during November 2005 and September 2006 following Hobbie et al. (1977) using acridine orange as the fluorochrome.

About $1 \mathrm{~g}$ wet sediment samples were suitably diluted using saline water blanks to attain 100 or 1000 fold dilutions. Two duplicate aliquots of $0.1 \mathrm{ml}$ and $0.2 \mathrm{ml}$ supernatants from both the dilutions were spread plated respectively on nutrient agar plates (prepared at least 5 days prior to plating) and selective media and incubated as mentioned above. About $1 \mathrm{~g}$ wet zooplankton samples were homogenized in a tissue blender with appropriate volumes of saline water blanks to attain 100 or 1000 fold dilutions and duplicate aliquots of $0.1 \mathrm{ml}$ and $0.2 \mathrm{ml}$ supernatants plated as done for sediments. Dry weights of all sediment and zooplankton samples used for enumeration of bacterial groups were determined and colony counts expressed on dry weight basis.

To reduce the uncertainties associated with counting the pathogenic bacteria as 'like organisms' for instance Escherichia coli like organisms (ECLO), we carried out appropriate biochemical and morphological tests. For this, a total 564 colonies of ECLO [109 isolates], Vibrio cholerae like organisms (VCLO; [102 isolates]), Streptococcus faecalis like organisms (SFLO; [102]), Salmonella like organisms (SALO; [102]) and Aeromonas like organisms (AALO; [102]) from different specific media were picked out, purified and characterized (unpublished results). We find that $\sim 75 \%$ of ECLO are EC and $\sim 72 \%$ each of VCLO, SFLO, SALO and AALO are VC, SF, SA and AA respectively. Using this information, "nearly true” percentages of EC, VC, SF, SA and AA from their 'LO' counts are calculated and presented here. 


\section{Results:}

In brief, the physico chemical characteristics in the study area were as follows. Depths at sampling locations in the study ranged from 3.8 to $20 \mathrm{~m}$, deepening offshore. During May 2005, the water temperature ranged from $28.0^{\circ} \mathrm{C}$ to $32.6^{\circ} \mathrm{C}$; during November 2005 from 27.6 to $28.9^{\circ} \mathrm{C}$ and during September 2006 from $27.4^{\circ} \mathrm{C}$ to $29.5^{\circ} \mathrm{C}$. Salinity ranged from 7.3 to $36.3 \mathrm{PSU}$ during September/November. It was quite high (34.7 to $36.7 \mathrm{PSU}$ ) during May. Concentrations of $\mathrm{NO}_{3}$; $\mathrm{PO}_{4}$ and, $\mathrm{SiO}_{4}$ respectively were in the range of 0.01-12.57 and 0.01-4.28; 0.05-0.51 and 0.02-1.8 and, 0.02-10.1 and 0.4-19.3 $\mu \mathrm{M}$ during May and November. Chlorophyll concentrations during these two sampling months ranged from 1.22 to11.45 and, 1.17 to $6.14 \mathrm{mgm}^{-3}$.

On the basis of media manufacturer's guide and on the knowledge of innumerable previous analyses, typical colony morphology characteristics of different bacterial groups were recognized and initial enumeration of pollution indicator and pathogenic bacteria was completed. Typical colony characteristics of each group are listed below:

McConkey Agar: all colonies grown on this medium counted as total coliforms. Typical, pink 2$3 \mathrm{~mm}$ dia colonies counted as Escherichia coli like organisms. M Enterococcus Agar was used for plating samples collected during May 2005. For later samples Enterococcus confirmatory agar was used: all colonies on M Enterococcus counted as streptococci. While those typically pink enumerated as Streptococcus faecalis like organisms. All colonies on Enterococcus confirmatory agar counted as streptococci. Those typically blue, $<2 \mathrm{~mm}$ dia were enumerated as Streptococcus faecalis like organisms. TCBS Agar: all colonies grown on this medium were counted as Vibrio like organisms. Sucrose fermenting, yellow, entire, raised $<2 \mathrm{~mm}$ dia colonies were counted as Vibrio cholerae like organisms. Punctate, raised, blush green, $\sim 1 \mathrm{~mm}$ dia colonies were enumerated as Vibrio parahaemolyticus like organisms. Hi Crome Salmonella Agar: reddish, small, round, convex colonies were counted as Salmonella spp (SA). Aeromonas Isolation Agar: yellow, entire 2-3 mm dia, glistening, convex colonies were counted as Aeromonas spp. 


\section{Total and indicator bacterial populations:}

Total direct counts (TDC) for water samples were the highest during month of November and the least during September (Figure 2). The mean TDC ranged from 2.5-3.3 $\left[\mathrm{X} 10^{6}\right] \mathrm{ml}^{-1}$ during November in coastal zone. In Marmugao Bay their number were more (2.6-22.7 $\left.\left[\mathrm{X} 10^{6}\right] \mathrm{ml}^{-1}\right)$ during November than during September $\left(1.9-6.0\left[\mathrm{X} 10^{3}\right] \mathrm{ml}^{-1}\right)$. During November their ranges were 15.9-16.3 $\left[\mathrm{X} 10^{6}\right] \mathrm{ml}^{-1}$ in Mandovi and, 2.7-9.3 $\left[\mathrm{X} 10^{6}\right] \mathrm{ml}^{-1}$ in Zuari locations. The TDC were quite low during September at these locations(Figure 2).

The sampling area covered for this study was quite large. Since we sampled 22 sites each season, the data collected are numerous. Thus, we present here the average abundances of different bacterial populations for each season from water (Figure 3) and other samples (Figure 4 and 5). While the differences in their abundances between the sampling locations are statistically insignificant (Table 1), strong signals of seasonal variations could be discerned. In the overall,

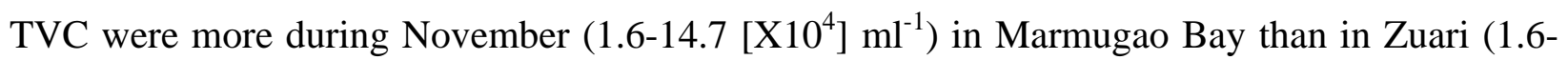
$5.0\left[\mathrm{X}_{10}^{4}\right] \mathrm{ml}^{-1}$ ). Similar was the case with the TC and TS (Figure 3). Owing to rough weather conditions, sampling was not possible from offshore stations 1, 2 and 3 during September 2006. In general, sediment samples had higher TC during November and their counts in increased downstream in both Zuari and Mandovi.

\section{Pathogenic Bacterial abundance:}

The abundance of five different types of pathogenic bacteria in water samples during different months is presented in Figure 3. During November, the counts of E. coli, VC and SA were generally more in the entire region. The seafood-borne pathogen, $V$. parahaemolyticus was

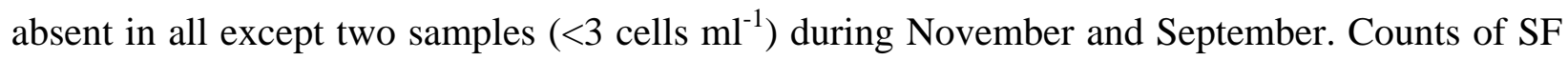
varied widely between seasons. Similar to most other pathogenic groups, the AA counts were high during November. Large variations in the abundance of different pathogenic bacterial types were evident in both sediment and zooplankton samples (Figs 4 and 5). Counts of EC, VC, SA, SF and AA were in the range of 0 to $1333 \mathrm{ml}^{-1}, 0$ to $3012 \mathrm{ml}^{-1}, 0$ to $1646 \mathrm{ml}^{-1}, 0$ to $613 \mathrm{ml}^{-1}$ and, 0 to $2760 \mathrm{ml}^{-1}$ respectively. . 


\section{Discussion:}

In line with the 'great plate count anomaly' (Staley and Konopka 1985), plate counts of all populations of bacteria enumerated in this study were less than 1 to $0.1 \%$ of the TDC. Notwithstanding the deficiencies, the culturable populations of bacteria are useful to obtain insights on the prevalence of certain pathogenic and/or sewage-pollution indicator bacteria.

Sewage contamination of aquatic habitats is detected by enumerating the coliform groups of bacteria (Fujioka 2002). As is universally accepted, higher sewage contamination would lead to increased numbers of coliforms in natural water bodies. Indiscriminate, deliberate, accidental or regular/routine disposals of sewage in most developing countries lead to higher abundance of coliform groups. Ecological surveillance for microbiological analysis is therefore necessary on a continuous basis for realizing the impacts of effluent discharges. Further, as innumerable pathogenic bacteria will constitute the microflora of effluents discharged from domestic, urban, agricultural and certain manufacturing practices, quantifying different groups of pathogenic prokaryotes ought to be part of such surveys. For instance, information on occurrence, abundance and distribution of potent human pathogens, Vibrio cholerae (causing cholera in humans), Vibrio parahaemolyticus (gastroenteritis), Salmonella and Shigella spp (typhoid fever; food poisoning), Streptococcus spp (meningitis and skin infections) and aeromonads (septicaemic conditions) in aquatic ecosystems may prove useful in public health management.

From a comparative assessment of distribution and abundance of pollution indicator and human pathogenic bacteria in the typically tropical estuaries of Mandovi and Zuari in the central west coast of India, it is inferred that the counts of all the groups are lower than those reported from other regions of the Indian coast (Ramaiah et al. 2004). In general, the highest abundance of all the examined groups was observed during November. However, the fecal coliform counts are lower than those reported from the coastal waters of Hong Kong (Ni and Lin 1986) and the Seine River and its estuary (George et al. 2001) and Mumbai waters (Ramaiah et al. 2004). Apparently, in most coastal locations around the world, the reported counts of coliforms and/or certain human pathogenic bacteria (APHA 1980; Cabelli 1983; Dufour 1984; Ni and Lin 1986; George et al. 2001; Ramaiah et al. 2004) are more than those observed in this study.

Microbiologists rely on the principle that higher the incidence of sewage indicator bacteria in any environment, higher would be the chances for human pathogenic bacteria to be present (Brock et al. 1994; Fujioka 2002). Further, bacterial metabolism is such that, if a particular group, say 
Vibrio cholerae is the dominant bacterium in the sewage discharges, it can compete and rapidly outgrow the native microflora leading to increased levels of indicator bacteria in natural water bodies. Pathogenic bacteria of human health concern have mostly been studied mostly for their survival in the marine environment (Huq et al. 1984, Byrd and Colwell 1990; Smith et al. 1994; Oliver et al. 1995). It is evident that the abundance of pathogenic bacterial we studied fluctuated widely in the water samples in the study area.

The bacterial load in sediment samples are reported to vary from as low as $9.3 \pm 1.1 \mathrm{X} 10^{6}$ to as

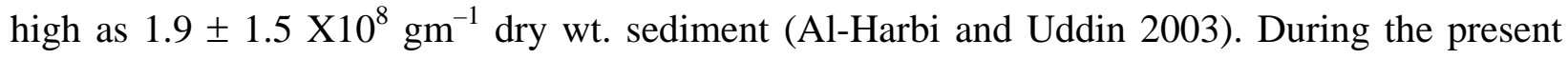
investigation the bacterial load TVC in the sediment was $<9.3 \pm 1.1 \mathrm{X}^{7} 0^{7} \mathrm{gm}^{-1} \mathrm{dry}$ wt. Higher TC, and their increasing numbers downstream in Zuari and Mandovi, imply cumulative effect of land drainages Further, both EC and SF were preponderant mostly during November throughout the region. These numbers, particularly in water samples, largely denote recent sewage/land drainage contamination. Such abundance in sediments is indicative of past contamination and, extended survival of these microflora mostly brought in through land drainages. In essence, premonsoonal abundance of both pollution indicator TC and human pathogenic bacteria is an indication of an ability of these allochthonous flora to endure and survive the benthic habitats. The ranges observed in this study are generally similar to those previously reported from the coastal environs of Goa (Ramaiah et al. 2002b)

Results from this study also indicate a strong association of general, indicator and human pathogenic bacteria with zooplankton. Association of general, pollution-indicator and pathogenic bacteria with zooplankton is a common feature (West and Lee 1982; Hansen et al. 1996; Islam et al. 2001; Signoretto et al. 2004; Dixon 2005). Such association in particular with copepods, the predominant zooplankton community, is reported to enhance the survival of microbial populations (Huq et al. 1984). Also, the molting of chitinous exoskeleton will enhance the availability of organic nutrients for the associated microflora. The fact that fecal pellets contain several species of bacteria including human pathogens (Hansen and Bech 1996) clearly suggests the proliferation of allochthonous microflora in the marine environment. Members of Vibrio spp., Aeromonas spp., Escherichia coli, Enterococcus spp., Campylobacter spp. and Arcobacter spp. have been reported from zooplankton samples (Dixon 2005).

This comparative assessment of distribution and abundance of pollution indicator and human pathogenic bacteria is helpful to infer that the tropical estuaries of Mandovi and Zuari experience 
impacts of sewage outfalls. These observations and ensuing inferences of this study are useful for managing effluent outfall into coastal ecosystems. Safeguarding the ecosystem from adding undesirable microbial populations calls for evolving appropriate policies and regulations. Every effort leading to reduction in pollution indicating bacteria and microbes of human health concern has to be promoted and implemented.

Acknowledgements: We thank Dr S R Shetye Director NIO, Dr A. C Anil, Project Leader, Ballast water control and management programme for facilities and encouragement. This is NIO contribution number...

\section{References:}

Al-Harbi, A.H. and Uddin, N. (2003). Quantitative and qualitative studies on bacterial flora of hybrid tilapia (Qreochromis niloticus X O. aureus) cultured in earthen ponds in Saudi Arabia. Aquaculture Research, 34, 43-48.

American Public Health Association (APHA), 1980, 'Standard Methods for the Examination of Water and Wastewater', 15th Edn, Washington, DC.

Brock, T., Madigan, M.T., Martinko, J.M. and Parker, J. (1994). Biology of Microorganisms (Seventh Edition)', Prentice hall, New Jersey.

Byrd, J. J. and Colwell, R. R. (1990). Maintenance of plasmids pBR322 and pUC8 in nonculturable Escherichia coli in the marine environment. Applied and Environmental Microbiology. 56, 2104-2107.

Cabelli, V.J. (1983). Health effects criteria for marine recreational waters, Environmental Protection Agency, Washington, D.C.

Colwell, R.R., Kaper, J. and Joseph, S.W. (1977). Vibrio cholerae, Vibrio parahaemolyticus, and other Vibrios: Occurrence and distribution in Chesapeake Bay. Science, 198, 394-396.

Colwell, R.R., Seidler, R.J., Kaper, J., Joseph, S.W., Garges, S., Lockman, H., Maneval, D., Bradford, H., Roberts, N., Remmers, E., Huq, I and Huq, A. (1981). Occurrence of Vibrio cholerae serotype $\mathrm{O} 1$ in Maryland and Lona estuaries. Applied and Environmental Microbiology, 4, 555-558.

Darakas, E. (2001). A simple mathematical formula describing the survival kinetics of $E$. coli in natural waters. International Journal of Environmental Studies, 58, 365-372. 
Dixon, B. (2005). Helicobacter from the seas? Studies around Italy’s coastline highlight potential dangers from human pathogens living in association with zooplankton. American society for microbiology, 71, 4-5.

Dufour, A.P. (1984). Bacterial indicators of recreational water quality. Canadian Journal of Public Health, 75, 49-56.

Fujioka, R., Roll, B. and Byappanahalli, M. (1997). Appropriate recreational water quality standards for Hawaii and other tropical regions based on concentrations of Clostridium perfringens: Proceedings of WEFTEC 97, 70 ${ }^{\text {th }}$ Annual Conference and Exposition, Surface Water and Ecology. Water Environment Federation, Alexandria, Va. 4, 405-411.

Fujioka, R. (2002). Microbial indicators of marine recreational water quality. In: Manual of Environmental Microbiology, Second edition. (eds: Hurst, C.J., Crawford, R.L., Knudsen, G., McIneney, M. J. and Stetzenbach, L. D.), American Society for Microbiology Press, Washington DC, 234-243.

George, I., Petit, M., Theate, C. and Servais, P. (2001). Distribution of coliforms in the Seine River and Estuary (France) studied by rapid enzymatic methods and plate Counts. Estuaries, 24, 94-102.

Hansen, B. and Bech, G. (1996). Bacteria associated with a marine planktonic copepod in culture.I.Bacterial genera in seawater, body surface, intestines and fecal pellets and succession during fecal pellet degradation. Journal of Plankton Reasearch, 18 (2), 257-273.

Hobbie, J. E., Daley, R.J. and Jasper, S. (1977). Use of nucleopore filters for counting bacteria by fluorescence microscopy. Applied and Environmental Microbiology, 33, 1225-1228.

Huq, A., West, P.A., Small, E.B. and Colwell, R.R. (1984) Influence of water temperature, salinity and $\mathrm{pH}$ on survival and growth of toxigenic Vibrio cholerae serovar $\mathrm{O} 1$ associated with live copepods in laboratory microcosms. Applied and Environmental Microbiology, 48, 420-424.

Islam, M.S., Siddika, A., Khan, M.N.H., Goldar, M.M., Sadique, M.A., Kabir, A.N.M.H., Huq, A. and Colwell, R.R. (2001). Microbiological analysis of Tube-well water in a rural area of Bangladesh. Applied and Environmental microbiology, 67 (7), 3328-3330.

Marchand, M. (1986). 'Ecological Study of Vibrios in Arcachon Bay, Second International Colloquium on Marine Bacteriology, Brest, 1-5, October 1984. Gerbam, CNRS, IFREMER, France, 3, 483-489. 
McCarthy, S.A. and Khambaty, F.M. (1994). International dissemination of epidemic Vibrio cholerae by cargo ship ballast and other nonpotable waters. Applied and Environmental Microbiology, 60, 2597-2601.

McCarthy, S.A. (1996). Effect of temperature and salinity on survival of toxigenic Vibrio cholerae O1 in seawater. Microbial Ecology, 31, 167-175.

Ni, C.Z. and Lin, Y.S. (1986). The primary investigation of fecal Escherichia coli group in Hong Kong coastal waters. Marine Science Bulletin of Haiyang Tongbao, 5, 45-48.

Oliver, J. D., Hite, F., McDougald, D., Andon, N. L. and Simpson, L. M. (1995). Entry into, and resuscitation from, the viable but nonculturable state by Vibrio vulnificus in an estuarine environment. Applied and Environmental Microbiology, 61, 2624-2630.

Patti, A.M., Paroli, E., Gabrieli, R., D'Angelo, A.M., De-Filippis, P., Villa, L. and Pana, A. (1987). Enteroviruses recovery from seawater: Statistical correlation with usual and chemical parameters, Ig. Mod. 87, 226-243.

Piccolomini, R., Cellini, L., Allocati, N., Gentili, E., Sartorelli, M. and Di-Girolamo, A. (1987) Microbiological pollution of seawater, Ig. Mod. 87, 543-552.

Ramaiah, N. and Chandramohan, D. (1993). Ecological and laboratory studies on the role of luminous bacteria and their luminescence in the coastal pollution surveillance. Marine Pollution Bulletin, 26, 190 - 201.

Ramaiah, N., Ravel, J., Straube, W.L., Hill, R.T. and Colwell, R.R. (2002a). Entry of Vibrio harveyi and Vibrio fischeri into the viable and nonculturable state. Journal of Applied Microbiology, 93, 108-116.

Ramaiah, N., Kenkre, V.D. and Verlecar, X.N. (2002b). Marine environmental pollution stress detection through direct viable counts of bacteria. Water Research, 36, 2383-2393.

Ramaiah, N. and De, J. (2003). Unusual rise in mercury resistant bacteria in coastal environments. Microbial Ecology, 45, 444-454.

Ramaiah, N., Kolhe, V. and Sadhasivan, A. (2004). Abundance of pollution indicator and pathogenic bacteria in Mumbai waters. Current Science, 87, 435-439.

Ruiz, G.M., Rawlings, T.K., Dobbs, F.C., Drake, L.A., Mullady, T., Huq, A. and Colwell, R.R. (2000). Global spread of microorganisms by ships. Nature, 408, 49-50. 
Sawkar, K., Pvethamony, Babu, M.T., Dias, C., Mesquita, A., Fernandes, B., Moses, S., Padmavati, M. and Naik, S. (2003). Measuring, modeling and grading the health of water bodies. Coastal tourism, environment, and sustainable local development, 179-210.

Shankar, D., Vinayachandran, P.N. and Unnikrishnan, A.S. (2004). The monsoon currents in the north Indian Ocean. Progress in Oceanography, 52, 63-120.

Signoretto, C., Burlacchini, G., Lleo, M., Pruzzo, C., Zampini, M., Pane, L., Franzini, G. and Canepari, P. (2004). Adhesion of Enterococcus faecalis in the nonculturable state to plankton Is the main mechanism responsible for persistence of this bacterium in both lake and seawater. Applied and Environmental microbiology, 70 (11), 6892-6896.

Smith, J. J., Howington, J. P. and McFeters, G. A. (1994). Survival, physiological response, and recovery of enteric bacteria exposed to a polar environment. Applied and Environmental Microbiology, 60, 2977-2984.

Staley, J.T., Konopka, A. (1985). Measurement of in situ activities of nonphotosynthetic microorganisms in aquatic and terrestrial habitats. Annu Rev Microbiol, 39, 321-46.

Thom, S., Warhurst, D. and Drasar, B.S. (1992). Association of Vibrio cholerae with fresh water amoebae. Journal of Medical Microbiology, 36, 303-306.

Wait, D.A. and Sobsey, M.D. (2000). Comparative survival of enteric viruses and bacteria in Atlantic Ocean seawater. Water Science and Technology, 43, 139-142.

West, P.A., and Lee, J.V. (1982). Ecology of Vibrio species, including Vibrio cholerae, in natural waters of Kent, England. Journal of Applied Bacteriology, 52, 435-448.

Xu, H.S., Roberts, N., Singleton, F.L., Attwell, R.W., Grimes, D.J. and Colwell, R.R. (1982). Survival and viability of nonculturable Escherichia coli and Vibrio cholerae in the estuarine and marine environment. Microbial Ecology, 8, 313-323. 


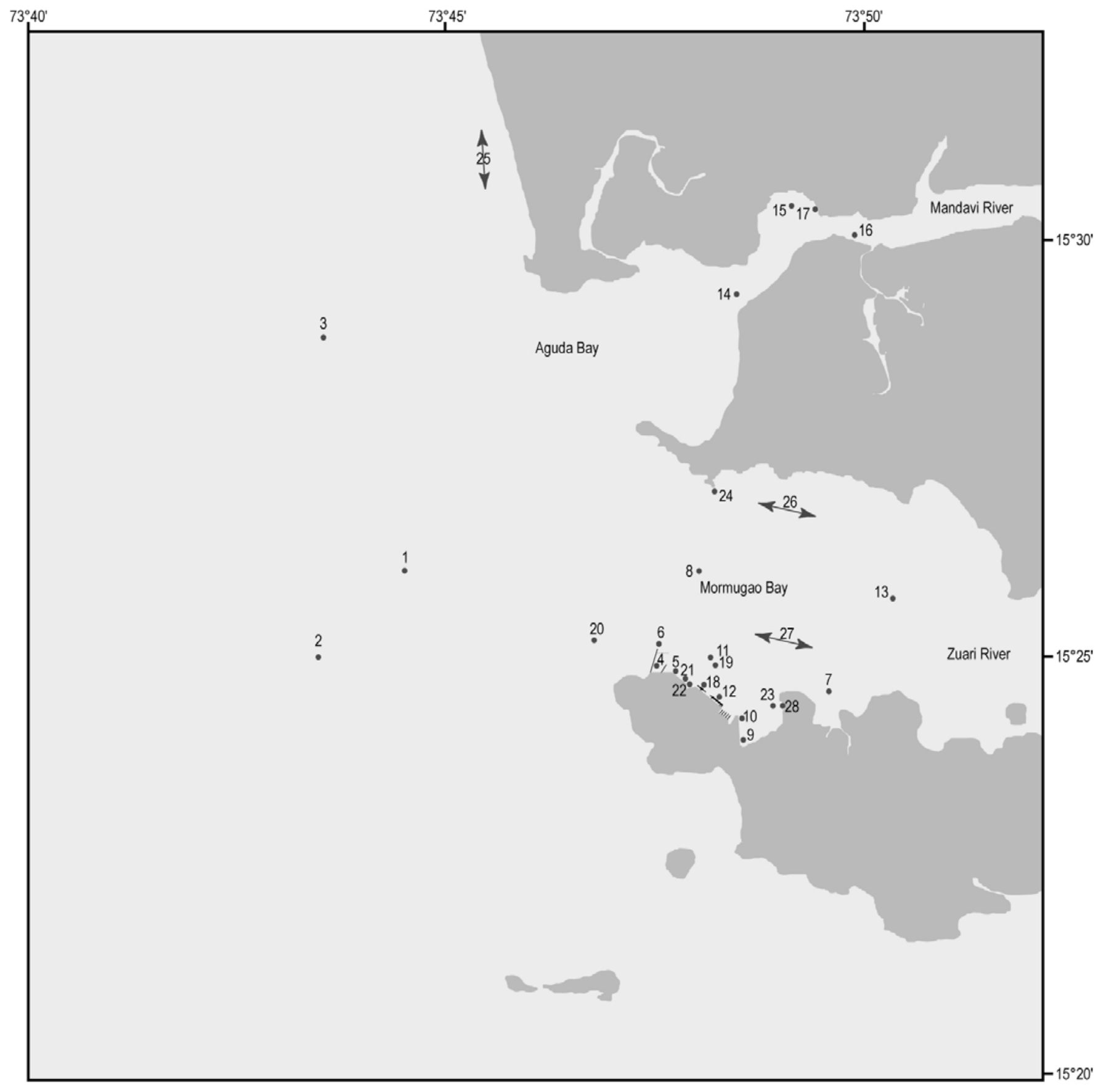

Figure 1. Map showing sampling locations in the study area of Mandovi-Zuari estuarine complex 


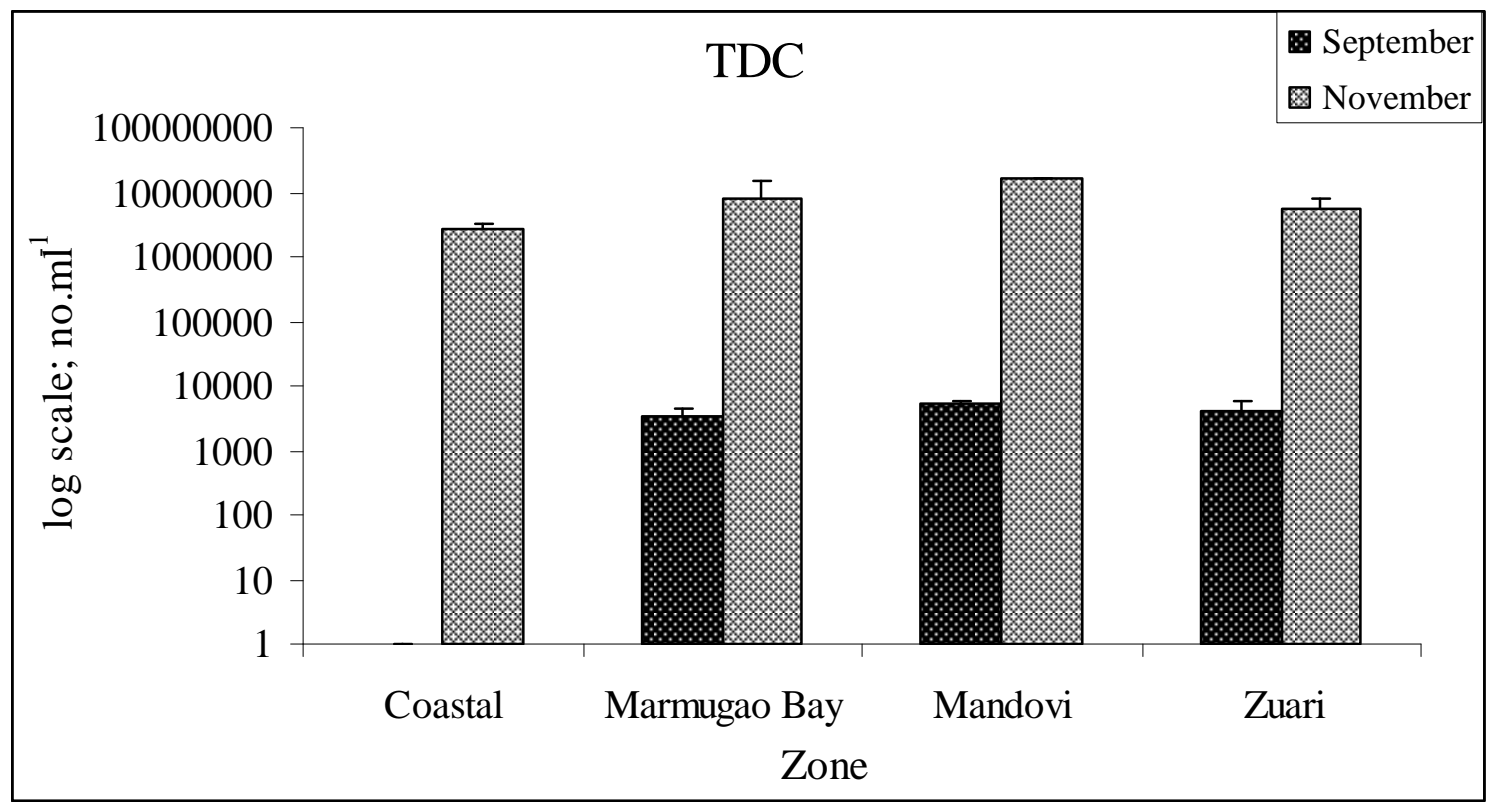

Figure 2. Total direct counts (TDC) of bacteria in water samples collected from Mandovi- Zuari estuarine complex during different seasons. 


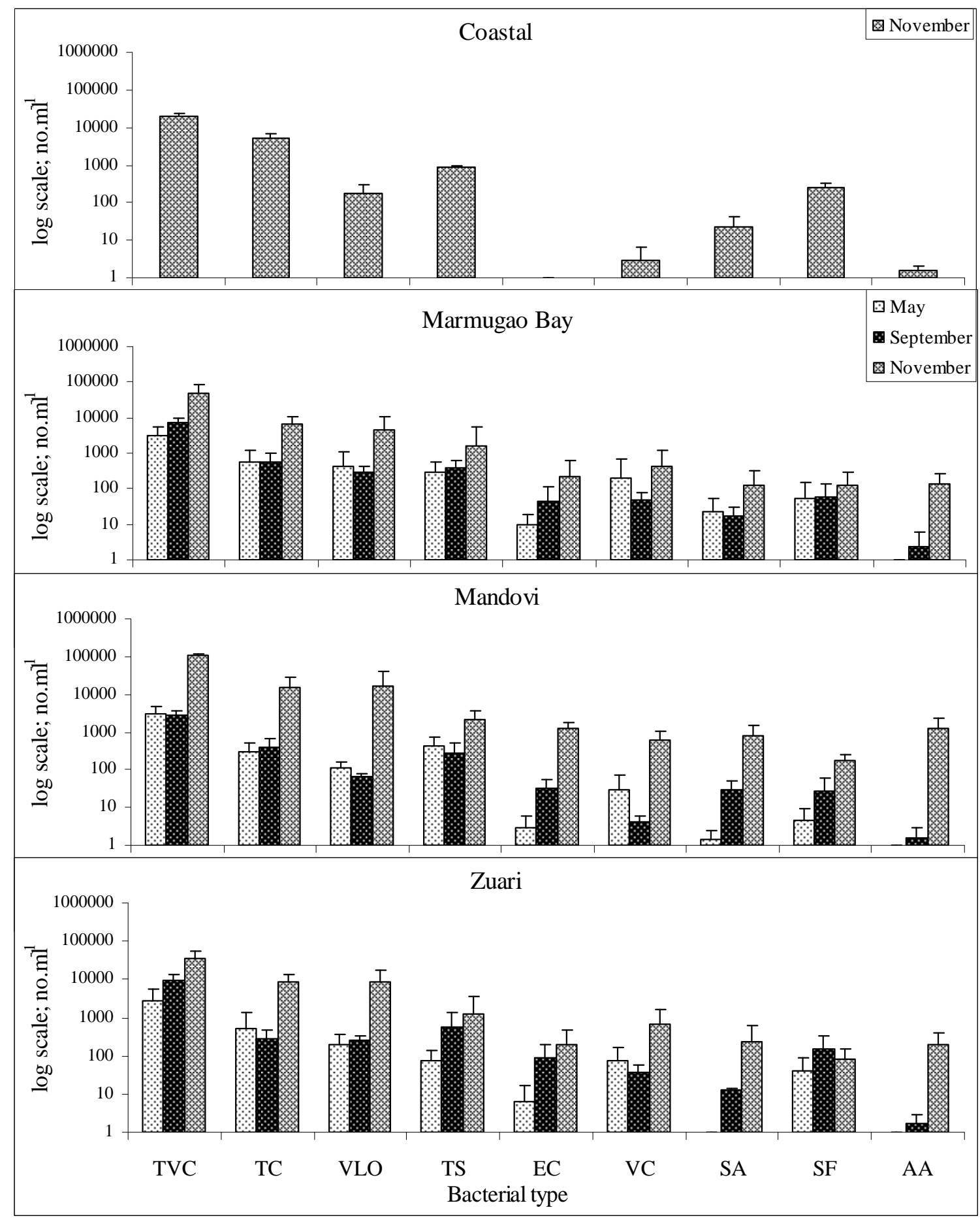

Figure 3. Indicator and pathogenic bacterial numbers in water samples collected from MandoviZuari estuarine complex during different seasons. TVC - total viable counts; TC- total coliforms; VLO- total vibrios; TS- total streptococci; EC- Escherichia coli; Vibrio cholerae; SASalmonella spp; SF- Streptococcus faecalis; F- Streptococcus faecalis; AA-Aeromonas spp 


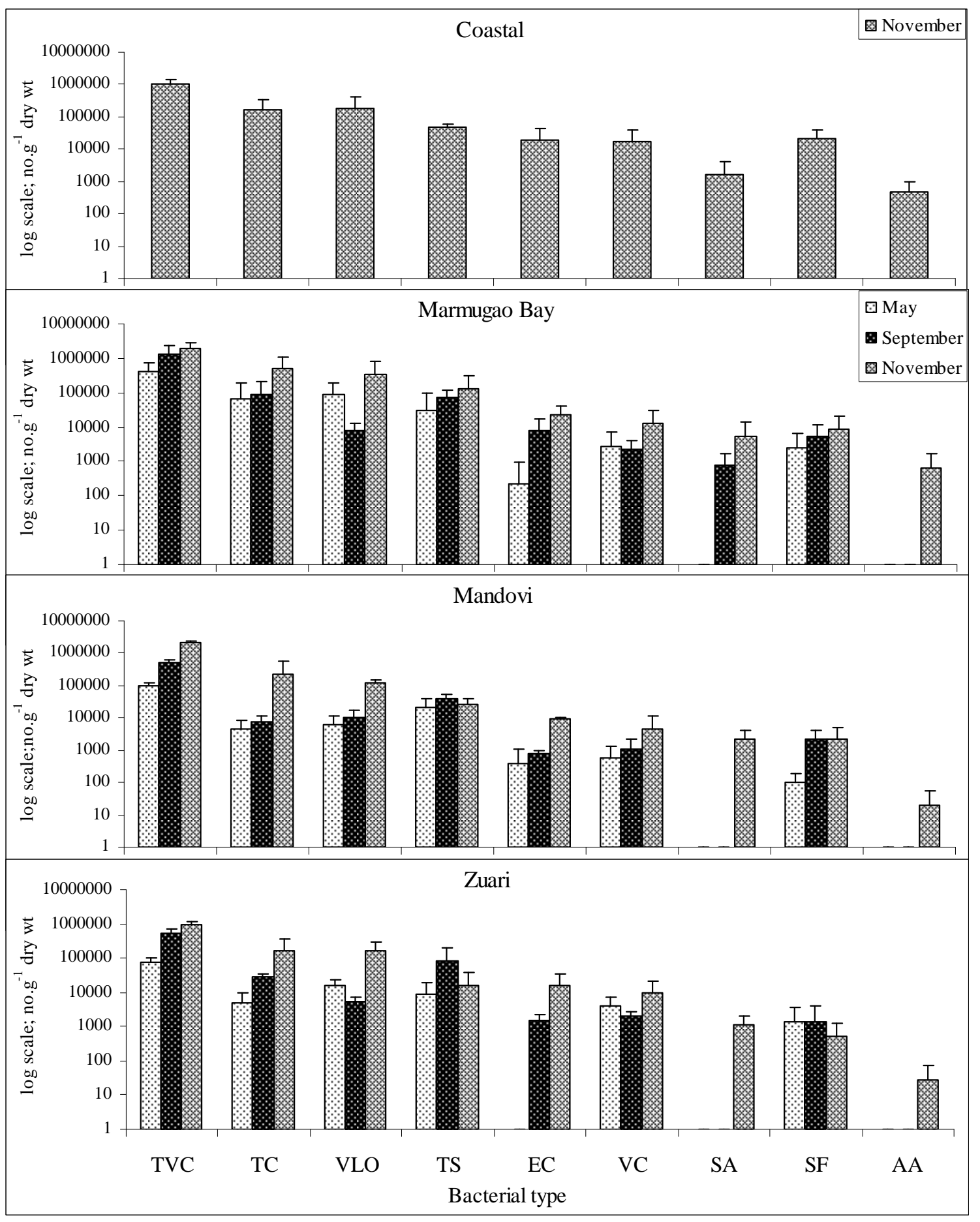

Figure 4. Indicator and pathogenic bacterial numbers in sediment samples collected from Mandovi-Zuari estuarine complex during different seasons. TVC - total viable counts; TC- total coliforms; VLO- total vibrios; TS- total streptococci; EC- Escherichia coli; Vibrio cholerae; SASalmonella spp; SF- Streptococcus faecalis; F- Streptococcus faecalis; AA- Aeromonas spp 


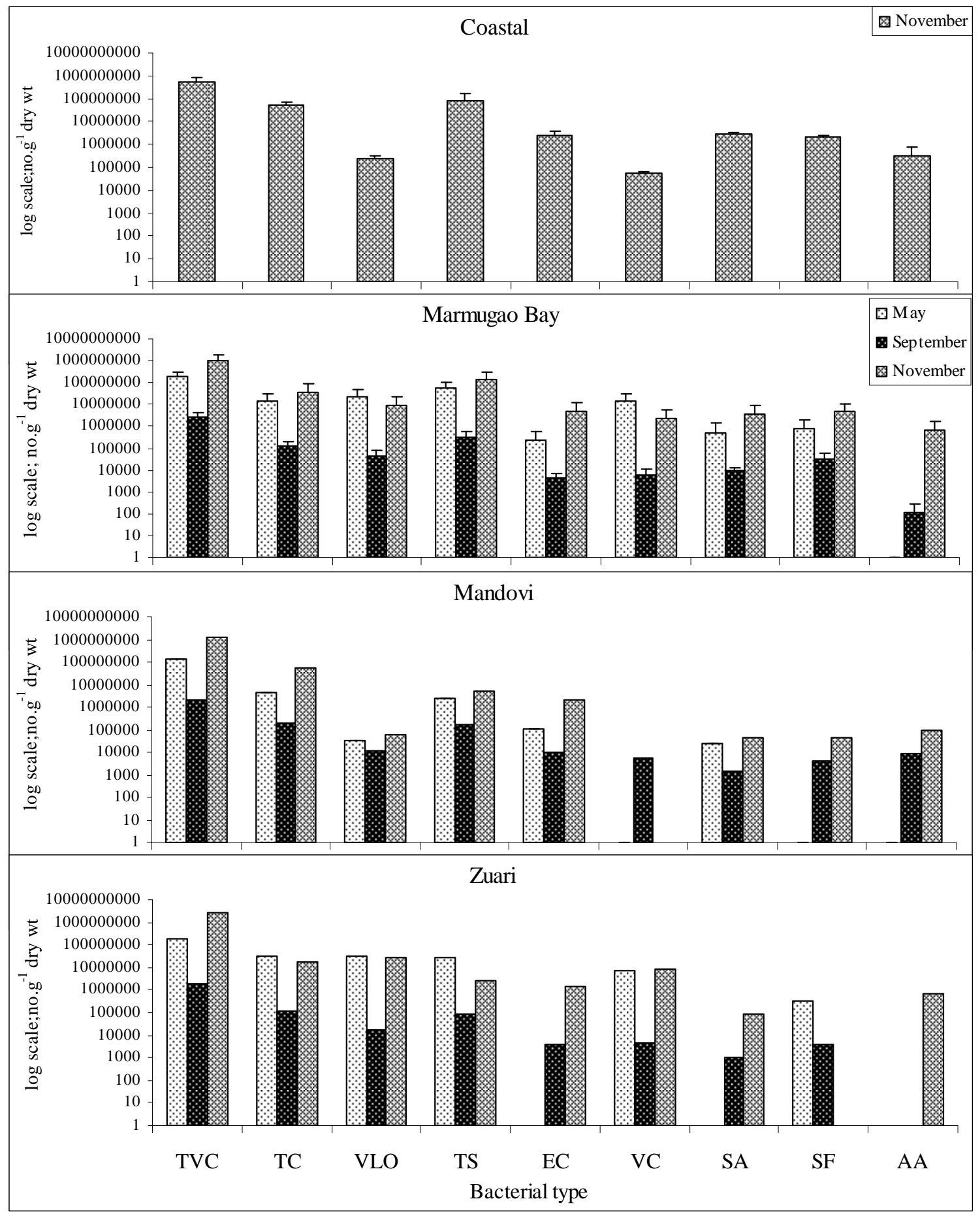

Figure 5. Indicator and pathogenic bacterial counts from zooplankton samples collected from Mandovi-Zuari estuarine complex during different seasons. Only one zooplankton sample collected from Mandovi and Zuari stations. TVC - total viable counts; TC- total coliforms; VLOtotal vibrios; TS- total streptococci; EC- Escherichia coli; Vibrio cholerae; SA- Salmonella spp; SF- Streptococcus faecalis; F- Streptococcus faecalis; AA-Aeromonas spp 
Table 1: Analysis of variance (ANOVA, $\left[\mathrm{F}_{18,2}\right]$ ) for different populations of bacteria to distinguish the effect of seasons and locations on their abundance

\begin{tabular}{llc}
\hline \multirow{2}{*}{ Bacterial type } & \multicolumn{2}{c}{ ANOVA $\left(\mathrm{F}_{18,2}\right)$} \\
\cline { 2 - 3 } TVC & Between seasons & Between locations \\
TC & $46.9021^{* * *}$ & 1.1574 \\
TS & 1.8091 & 1.8224 \\
VLO & $26.1322^{* * * * *}$ & 1.1626 \\
VC & $8.4839^{* * *}$ & 1.7142 \\
SA & $14.2818^{* * *}$ & 1.4905 \\
AA & $34.0359 * * *$ & 1.6329 \\
EC & $11.2339 * * *$ & 1.0646 \\
SF & $6.5391 *$ & 0.5467 \\
\hline
\end{tabular}

*** significant at $p<0.0001$; *significant at $p<0.001$; other values not significant. TVC - total viable counts; TC- total coliforms; VLO- total vibrios; TS- total streptococci; EC- Escherichia coli; Vibrio cholerae; SA- Salmonella spp; SF- Streptococcus faecalis; F- Streptococcus faecalis; AA-Aeromonas spp 